高分子論文集 (Kobunshi Ronbunshu), Vol. 51, No. 12, pp. 789 -794 (Dec., 1994)

\title{
ポリビニルプロピオナール樹脂の光劣化挙動と 還元処理による光劣化性の改善
}

\author{
山本＼cjkstart隆*1・清田 徹*1
}

（受付 1994 年 5 月 24 日・審查終了1994 年 6 月 20 日）

\begin{abstract}
要 旨 ポリビニルプロピオナールからなるフィルムに波長 $365 \mathrm{~nm}$ の紫外光を照射し、フィルムの光劣化挙動 について検討した，各種スペクトルによる構造解析の結果から，フィルムの光劣化はポリビニルアルコールの劣化 と同様の光酸化劣化反応によるものであると推定した．この推定メカニズムに基づき，樹脂中に微量に存在する主 鎖カルボニル構造および共役エノン構造を、樹脂の還元処理によって化学的に除去した結果, 樹脂の光劣化性を大 幅に改善できることを見いだした。
\end{abstract}

\section{1 舶言}

ポリビニルアセタールは, ポリビニルアルコール（以 下PVA と略記）とアルデヒドとのアセタール化反応に よって合成される ${ }^{1) ~}$. ポリビニルアセタールはその透 明性, 光劣化耐性, およびフィルム形成性に優れること から, 光学用フィルムとしての応用が検討されてい るいて). しかし，これらポリビニルアセタールにおいて あ長期間にわたる紫外光の照射によっては劣化を生じ, 最終的にはフィルムの着色や, 膜厚の減少によるフィル ム強度の低下などをきたす7), 8).

本研究では, ポリビニルアセタール樹脂フィルムの光 劣化のメカニスムについて調查し, ついで光劣化防止の ための手法について検討した. 従来, PVA の光劣化機構 については, 数多くの興味ある研究結果が報告されてい る9 11). しかしながら, そのアセタール化体であるポリ ビニルアセタールについては，おまり報告例をみない. 我々は,このようなポリビニルアセタールの中であ, プ ロピオンアルデヒド (以下 ProAld と略記) とのアセ タール化体であるポリビニルプロピオナール（以下 PVP と略記）に注目し，そのフィルムに対して，波長 $365 \mathrm{~nm}$ の単色柴外光を連続照射し，このフィルムの光劣化挙動 について検討した. さらに，これらの結果から推定され る樹脂の光出化機構に基づき，光出化に対して優れた耐 久性を持つPVP の合成を試みた。

\section{2 実験}

\section{1 試料}

PVPの原料となる PVA（クラレ(株)製）としては重

*1 東ソー(株) 新材料研究所 (-252 神奈川県綾瀬市早川 27431)
合度 1000 の完全けん化物を使用した。 アセタール化溶 媒にはイオン交換水。およびメチルアルコール（以下 $\mathrm{MeOH}$ 之略記)（和光純薬(株)製試薬特級）を用いた. ア ルデヒドはPrAld（三菱化成(株)製）を常圧で蒸留 (47 $\sim 48^{\circ} \mathrm{C}$ 留分) して用いた。. 触媒は $35 \%$ 塩酸（和光純薬 （株)製試薬特級）を用いた。 また，PVP の還元反応を行 う際の反応溶媒であるテトラヒドロフラン（以下 THF と略記), ジオキサン, ヘキサメチルフォスフォリックト リアミド（以下 HMPA と略記）(以上全て和光純薬(株) 製試薬特級）は，いずれもモレキュラーシーブスを用い て十分に脱水精製して使用した，還元剤は水素化アルミ ニゥムリチゥム (以下 $\mathrm{LiAlH}_{4}$ と略記), 金属ナトリゥム （以下 $\mathrm{Na}$ と略記）（以上いずれす和光純薬(株)製試薬特 級）を用いた。 上記の試料のうち，精製に関して特に記 述のない試料については市販品をそのまま使用した。

\section{2 合成方法}

2.2.1 PVP の合成 PVA $(100 \mathrm{~g})$ と $\mathrm{MeOH}(950 \mathrm{ml})$ とからなる混合物を $2 l$ 容のセパラブルフラスコに入 れ,これにかくはんモーターを取り付け, 窒素芬囲気下, 室温にて 30 分間かくはんした。続いて 35\% 塩酸 (20 $\mathrm{m} l$ ) を一括投入した後，セパラブルフラスコを $52 \sim 53^{\circ} \mathrm{C}$ に設定された恒温槽に浸せきした. 混合物の温度が $52^{\circ} \mathrm{C}$ 付近に到達したところで, ProAld $(230.8 \mathrm{~g})$ を滴下漏斗 にて約 60 分間かけて滴下した. 滴下終了後, 恒温槽の温 度を 52 53ㄷ に設定した状態で，さらに 96 時間反応を 行なった: その後, 生成したモ千状の沈殿物をデカン テーションによって回収した後,アセトン $(3.2 D)$ に溶解 させて溶液とした，この溶液を，激しくかくはんしたイ オン交換水中に滴下してポリマーを析出させた，得られ たポリマーを十分に水洗した後, 真空乾燥した。

2.2.2PVP の這元 (LiAlH4 通元) 2.2.1 で得られた 
山本・清田

PVP (10 g) を脱水精製した THF に窒素気流下で溶解 し, $10^{\circ} \mathrm{C}$ 以下に冷却した。 この溶液に $\mathrm{LiAlH}_{4}(1.0 \mathrm{~g})$ と 脱水 THF $(150 \mathrm{~m} l)$ とからなる分散液を $10^{\circ} \mathrm{C}$ にて 30 分 ぐらいでゆっくりと滴下した後，加熱を行い，還流条件 にて 2 時間還元反応を行った。 反応終了後室温まで放冷 し, $\mathrm{MeOH}(50 \mathrm{ml})$ を添加して室温で 18 時間汃くはんし てから，未反応の $\mathrm{LiAlH}_{4}$ を処理した。 反応溶媒を減圧 留去した後, 得られた反応混合物にイオン交換水 $(200$ $\mathrm{ml})$ を加え, 塩化メチレン $(100 \mathrm{ml})$ で 3 回抽出を行っ た. 塩化メチレン層を塩化カルシウムで乾燥した後, 万 過によって塩化カルシウムを除き, 得られた溶液をイオ ン交換水に滴下してポリマーを析出した。 得られたポリ マーを繰り返し水洗し, 真空乾燥した.

2.2.3 PVP の這元（Na/HMPA 這元） 脱水精製した HMPA $(1000 \mathrm{ml})$ をかくはんモーターを取り付けた $2 l$ 容のセパラブルフラスコに入れ, 室素要囲気下でかくは んしながら Na (5 g) を少しづつ投入し, 液が濃い青色を 呈するまで室温でかくはんさせ，Na と HMPA とからな る溶液を調整した。これとは別に2.2.1で得た PVP $(50 \mathrm{~g})$ を乾燥精製したジオキサン $(500 \mathrm{~m} l)$ に溶解させ, この溶液を先の Na の HMPA 溶液に対して, 窒素気流 下で滴下漏斗を用いて, 約 4 時間かけて室温にてゆっく りと滴下した。 滴下終了後さらに 16 時間室温で反応を 続け，エチレングリコールモノエチルエーテル $(100 \mathrm{ml})$ を加えて反応を停止した，得られた溶液をイオン交換水 4 lに滴下して, ポリマーを析出させた. ポリマーを水で 繰り返し洗浄した後, 真空乾燥した.

2.3 ポリマーのキャラクタリゼーション

2.3.1 アセタール化度の定岳 合成した PVP 樹脂の アセタール化度の定量は, JISK6728-1977に規定されて いる酸塩基滴定法によって求めた. アセタール化度は式 (1)のように定義した。

アセタール化度 $(\mathrm{mol} \%)$

$$
=100 \text {-(水酸基+残存アセチル基) }
$$

2.3.2 分子吾の測定 ポリマーの分子量の測定はゲ ルパーミネーションクロマトグラフ法（以下 GPC 法と 略記)によって行った。 GPC装置は東ソー(株)製 HPLC 8000 システムを用い，カラムは東ソー(株) 製 G3000 HXL および G4000HXL を直列でつないで使用した。溶 離液はテトラヒドロフランを使用し，分子量は標準ポリ スチレンを用いて換算法にて算出した。

2.3.3 吸光度の測定 ポリマーの吸光度は島津製作 所製 UV-260を用いて求めた. PVP の場合は塩化メチレ ン（ドータイト，スペクトロゾール）を溶媒として $3 \mathrm{wt}$ \% 濃度で，またPVP の場合はイオン交換水を溶媒とし て同じく $3 \mathrm{wt} \%$ 濃度で, それぞれ光路長 $1 \mathrm{~cm}$ の石英セ ルを用いて, 各々の溶媒を対照として測定した。

\section{4 フィルムの形成}

PVP フィルムの形成は以下の手順で行った。まず PVP $(20 \mathrm{~g})$ をシクロへキサノン $(190 \mathrm{ml})$ に溶解させ約 $9.4 \mathrm{wt} \%$ の溶液とした. この溶液をポアサイス $0.22 \mu \mathrm{m}$ の四フッ化エチレン製メンブランフィルター（住友電工 （株)製フロロポアFP-022）でろ過し，異物を除去した。 この溶液を, あらかじめ撜水処理を行ってあるシリコ ウェハ上にスピン塗布し，続けてウェハを $120^{\circ} \mathrm{C}$ に調節 したホットプレート上で加熱処理して塗膜を乾燥させ, 厚さ $1.45 \mu \mathrm{m}$ のポリマー被膜を得た。得られた被膜を ウェハ上から注意深く翗がし取り, 接着剤をあらかじめ 至布しだー片 $90 \mathrm{~mm}$ のアルミ製の枠状体の上にピンと 張った状態で固着した.このようにして得た PVP 製の 中空フィルムを, 紫外光照射用のサンプルとして用い た.

\section{5 紫外光の照射}

2.4 で得たフィルムに対し, 以下のようにして紫外光 を照射した. 照射した紫外光は波長 $365 \mathrm{~nm}$ の単色光で あり，超高圧水銀灯 (ウシオ電機(株)製 ML-501D/B)よ り発生する紫外光のうち波長 $365 \mathrm{~nm}$ の光成分のみを干 涉フィルターを用いて取り出したものを使用した。照射 はフィルム全体に対し均一の照度となるように行った。 また, この時の照度は $30.4 \mathrm{~mW} / \mathrm{cm}^{2}$ であった.

\section{6 フィルムの光劣化状管の評価}

2.6.1 IR 測定 日本分光(株)製 IR-810を用い，紫外 光を照射したポリマーフィルムを試料光束側へ㨂入し て, 直接測定した.

2.6.2 透過率测定 (株)島津製作所製 UV-260 用 い, 紫外光を照射したポリマーフィルムを試料光束側へ 挿入して, その分光透過率を直接測定した.

2.6.3 フィルム膜厚の評価 紫外光未照射時のフィ ルムの膜厚については, フィルムの作成工程において, シリコンゥェハ上にポリマー乾燥被膜を形成した段階 で, 大日本スクリーン(株)製光学式膜厚計ラムタェース を用いて測定した，紫外光照射時における各段階での膜 厚は, まず 2.6.2 と同様にしてフォルムの透過率を測定 し, 得られた透過率の特定波長ごとの光学的干渉現象 (エタロニング： etaloning) を利用して, $365 \mathrm{~nm}$ 付近で透 過率が極大となる波長の, 膜厚变動に伴う変化量の実測 值から, 式 (2) および式 (3) を用いて計算により求め た.

$$
\begin{aligned}
& T=\frac{1}{1+\frac{4 R}{(1-R)^{2}} \times \sin ^{2} \frac{2 \pi n(\lambda) h}{(\lambda)}} \\
& R=\frac{(n(\lambda)-1)^{2}}{(n(\lambda)+1)^{2}}
\end{aligned}
$$

$h$, フィルム膜厚; $n(\lambda)$, 届折率; $T$, 透過率

この際, フィルムの届折率は $\lambda=365 \mathrm{~nm}$ における PVP 
フィルムの実測値 $n(365)=1.520236$ を用い, この値が紫 外光照射によるポリマーの構造変化によっても変動しな いものと仮定した.

2.6.4 'H NMR 测定 紫外光を照射したポリマー フィルムを $\mathrm{CDCl}_{3}$ 溶媒に溶解させトリメチルシラン (TMS) を基準として測定を行った，測定には日本電子 （株)製 JNMGX400FT-NMR を用いた。

2.6.5 分子吾娜定 紫外光を照射したポリマーフィ ルムをテトラヒドロフラン (THF) に溶解させ, 2.3 .2 と 同様の GPC 法によってポリスチレン換算の分子量を求 めた.

\section{3 実験と結果}

\subsection{PVP の評洒}

得られた PVP については, IR, ${ }^{1} \mathrm{H}$ NMR の各スペクト ル, アセタール化度, および分子量の測定による構造の 同定を行った。酸塩基滴定法によって求めたアセタール 化度は $89.5 \mathrm{~mol} \%$, GPC 法によって求めた数平均分子量

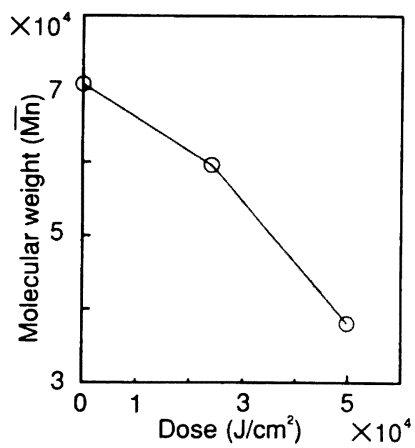

Fig. 1. Change of the number average molecular weight $\left(\bar{M}_{n}\right)$ of poly(vinyl propional) upon irradiation with $365 \mathrm{~nm}$ UV light.

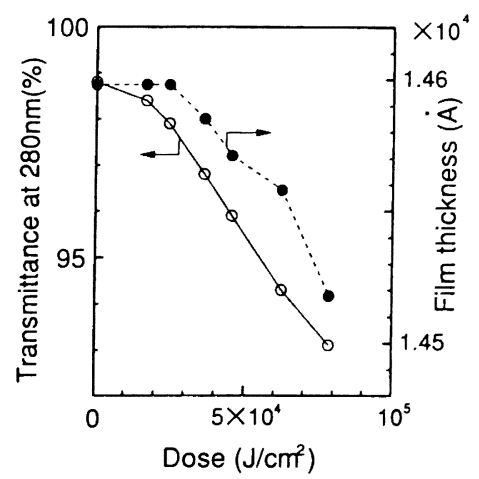

Fig. 2. Decrease in the transmittance at $280 \mathrm{~nm}$ and the film thickness of poly(vinyl propional) upon irradiation with $365 \mathrm{~nm}$ UV light.
$\left(\bar{M}_{n}\right)$ は 70680 であった.

\section{2 紫外光照射時の構造変化}

次にPVP のフィルムを形成し，これに紫外光を照射 してその挙動について評価した．紫外光の照射を十分に $\left(50000 \mathrm{~J} / \mathrm{cm}^{2}\right.$ 以上）行ったフィルムについては，外見的 なシワやタルミの発生や, 膜強度の低下がみられ，一見 して劣化している状況が確認できる.このフィルムの劣 化がポリマーのよ゙のような構造変化によるものかを GPC 測定および各種スペクトルによって検討した.

3.2.1 分子量の低下 同一のPVPから調整された紫 外光の照射量の異なるフィルムの分子量を GPC 法によ り各々測定し, 照射エネルギー量に対してプロットし,

Fig. 1 に示した， 紫外光の照射に伴い，大幅な分子量の 低下がみられ, 光反応によるポリマー主鎖の切断が生じ ていることがわかった。

3.2.2 フィルム膜厚の減少 紫外光照射時のフィル 么膜厚の推移について, フィルム透過率の推移とともに Fig. 2 に示した. 膜厚は紫外光の照射につれて減少して おり, ポリマーの光分解によって何らかの成分が分解, 揮散しているすのと考えられる.これは先に述べたポリ マーの低分子量化の結果と一致するあのである. しかし ながら,この膜厚の変化が, 後で詳細に述べる透過率の 変化と異なる点として, 膜厚の隇少が紫外光の照射によ り直ちに引き起こされるものではなく，いくらかの誘導 期を経た後に開始されている点が注目される.

3.2.3 透過率の変化 次にこのフィルムの紫外光照 射前後での透過率スペクトルについて検討を行った。透 過率スペクトルの注意深い観察から，約 220,280, 330 $\mathrm{nm}$ の各波長における透過率が徐々に低下してきてお り，これらの各波長をピークとする吸収帯がフィルム中 に発生していることが確認できる (Fig. 3).このうち,

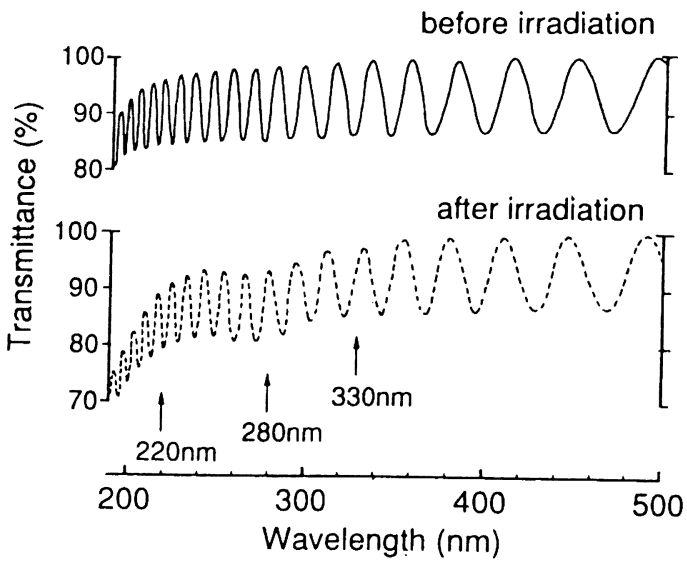

Fig. 3. Decrease in the transmittance of a poly (vinyl propional) film at $220,280,330 \mathrm{~nm}$ after irradiation with $365 \mathrm{~nm}$ UV light of $53000 \mathrm{~J} / \mathrm{cm}^{2}$. 
Dose:

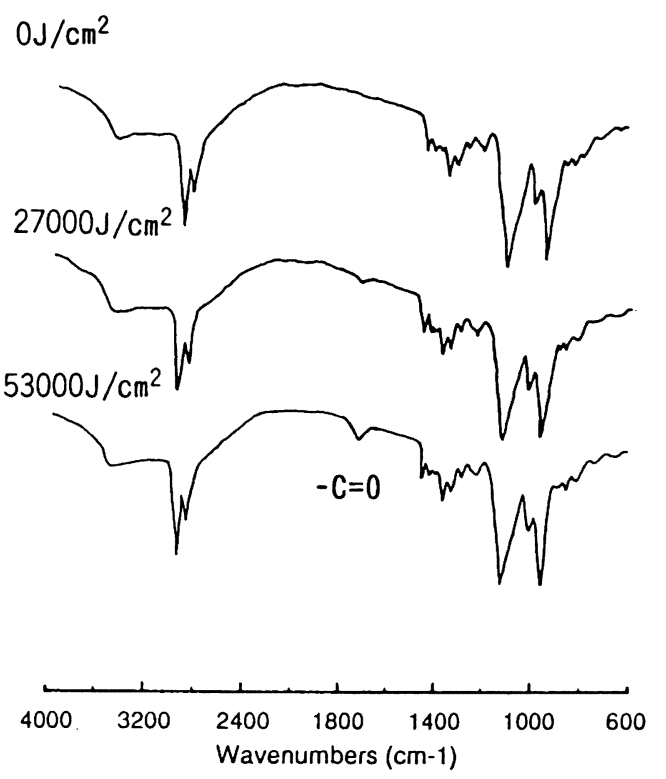

Fig. 4. IR spectra of a poly(vinyl propional) film bffore and after irradiation with $365 \mathrm{~nm}$ UV light.

最す顕著に透過率が低下する $280 \mathrm{~nm}$ 付近に注目し, 280 $\mathrm{nm}$ での透過率の推移を紫外光の照射エネルギー量に対 してプロットした結果が, 先ほどの Fig. 2 に示された透 過率の推移である. この結果から分かるとおり, 透過率 は紫外光照射開始直後からほぼ一定の速度で低下してお り,このことは紫外光照射により何らかの構造变化がポ リマー中に直ちに生じていることを示すすのである.

このような特徴的な三つの吸収帯とその構造について は, PVA の場合においては比較的良く知られている゙ . すなわち、これらの吸収は光または熱的な劣化に伴っ て, PVA 主鎖に生成する共役エノン構造 $-(\mathrm{CH}=\mathrm{CH})_{n}-\underset{\mathrm{O}}{\mathrm{C}}-$

によるものと極めて良く一致している.PVA の場合 220 $\mathrm{nm}$ の吸収は $n=1,280 \mathrm{~nm}$ は $n=2,330 \mathrm{~nm}$ は $n=3$ の場 合の構造にそれぞれ相当する. 我々はこれと同様の構造 変化が PVP のフィルム中においても発生しているすの と推定し, 各種スペクトル測定による確認を試みた.

3.2.4 カルボニル成分の增加 Fig. 4 に紫外光照射前 後でのフィルムの IR スペクトルを示した. 光照射につ れて $\mathbf{C}=\mathbf{O}$ 伸樎振動に由来するピークの発生がみられ, 光反応によってポリマー中にカルボニル基が生成してい ることが確認された。

3.2.5 二重站合成分の増加 紫外光照射前後のフィ ルムの ${ }^{1}$ H NMR スペクトルを比較して Fig. 5 に示した.
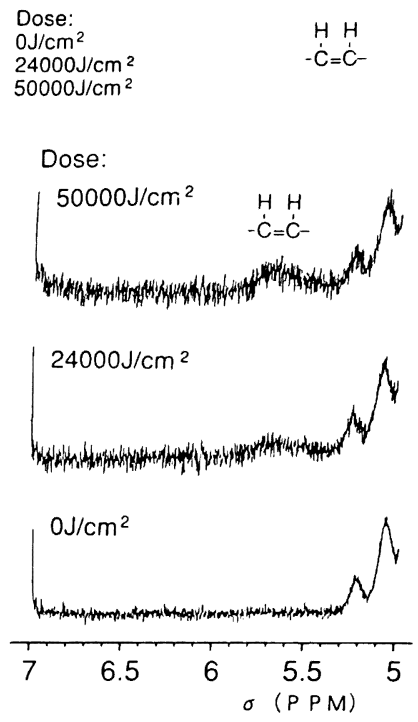

Fig. 5. 'H NMR spectra of poly(vinyl propional) before and after irradiation with $365 \mathrm{~nm}$ UV light.

これらは, 紫外光照射量の異なる各々のフィルムから調 整したサンプルの, $\mathrm{CDCl}_{3}$ 溶媒中での $5 \mathrm{ppm}$ 付近のシグ ナルの拡大図を示したあのである. 紫外光の照射につれ て $5.5 \mathrm{ppm}$ 付近にオレフィン部のプロトンに由来すると 思われる新たなシグナルの発生がみられ, 光反応により ポリマー中に二重結合成分が生成しているものと考えら れる.

\section{3 光出化反応に関する考察}

紫外透過率スペクトルによる特徵的な三つの吸収帯の 発生に加え, IR 吸収スペクトルにおけるカルボニル吸 収の発生, および ${ }^{1} \mathrm{H}$ NMR スペクトルによるオレフィ ンプロトンシグナルの発生は、いずれる共役エノンの生 成を裏付けるるのであった。これらの各種スペクトルの 結果から，PVA のアセタール化体である PVPにおいて あ, 光劣化に伴いPVA と同等の主鎖カルボニル基、お よびこれに続く共役エノン構造

$(\mathrm{CH}=\mathrm{CH})_{n}-\underset{\mathrm{O}}{\mathrm{C}-}$

の生成反応が進行しているあのと推定された. また，こ れらの共役エノン構造の生成に続く樹脂の主鎖解裂につ いては, さらに以下のように推定した。 つまり, 生成し たエノンは $n=1$ または 2 の場合においては，照射光の 波長である $365 \mathrm{~nm}$ での吸光度が極めて低いため, この 状態で直ちに紫外光を吸収して光励起され主鎖解裂を引 き起こすことは考えにくい，劣化反応がさらに進み $n=$ 3 程度まで酸化が進行した時点で波長 $365 \mathrm{~nm}$ の紫外光 を強く吸収するようになり，引き続いて主鎖の切断など が起こるものと推定される.このことは, 3.2.3で述べた 
ポリビニルプロピオメール樹脂の光劣化挙動と還元処理による光劣化性の改善

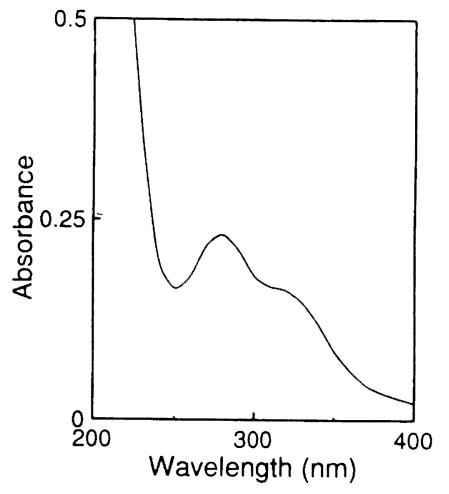

Fig. 6. Ultraviolet absorption spectrum of a $3 \mathrm{wt} \%$ aqueous solution of poly(vinyl alcohol).

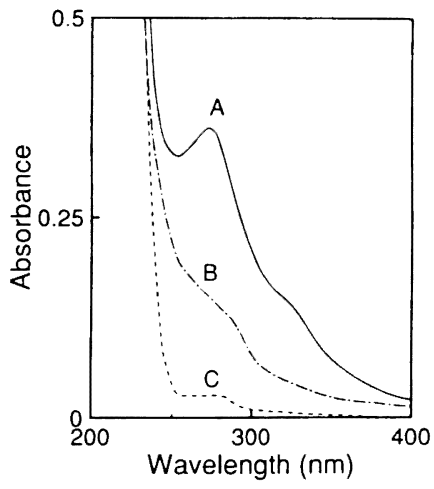

Fig. 7. Ultraviolet absorption spectra of the oridinal poly(vinyl propional) and reduced poly(vinyl propional) in dichloromethane solutions at a $3 \mathrm{wt} \%$ concentration: (A) oridinal PVP; (B) treated with $\mathrm{LiAlH}_{4} ;$ (C) treated by $\mathrm{Na} / \mathrm{HMPA}$.

透過率の低下が紫外光の照射開始直後から生じるのに対 し, 3.2.2で述べた膜厚の減少が誘導期をもって開始さ れることに対する一つの説明として成り立つ.

\section{4 光劣化耐性の改善}

次に, 光劣化反応に関するこれらの推定メカニズムを 基に，波長 $365 \mathrm{~nm}$ の紫外光照射時の光劣化に対して優 れた耐久性を持つPVPの合成について検討した，耐久 性を向上させるための仮説を以下の 2 点に基づいて設定 した. 光劣化反応がポリマー中に生成した主鎖カルボニ ルおよび共役エノン構造によって始動されていると推定 される点，およびこれらの主鎖カルボニルおよび共役工 ノン構造は原料とする PVA の時点で, 極めて微量では あるがすでにポリマー中に含まれている点である. PVA 中の共役エノン構造については，これまでにも多くの研 究者によって述べられているとおりである゙”。 また我々

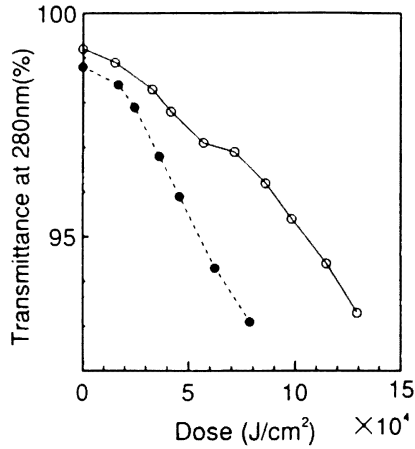

Fig. 8. Decrease in the transmittance of reduced poly (vinyl propional) at $280 \mathrm{~nm}$ upon irradiation with 365 nm UV light: $\bigcirc$, reduced PVP; $\bigcirc$, oridinal PVP.

が原料として用いた PVAにおいても，吸光度測定に よって, その特徴的な吸収が確認された (Fig. 6).

つまり，我々はこれらの主鎖カルボニルおよび共役エ ノン構造のうち, 光照射以前の PVP 中に最初から含ま れるものについてはあらかじめ化学的に除去することに より，ポリマー中の光劣化による共役エノン構造の生成 をある程度抑止することができ，光劣化に対してより優 れた耐久性を有する PVPを得ることができるのではな いかとの仮説を立てた．その具体的な化学的除去法とし て PVP の還元処理について検討した。

\section{5 遇元処理}

PVP の還元は $\mathrm{LiAlH}_{4}$ による方法と $\mathrm{Na} / \mathrm{HMPA}$ によ る方法の 2 通りを行った。 還元処理したポリマーについ ては GPC, 'H NMR, IR の各スペクトルおよびアセター ル化度の測定によるキャラクタリゼーションを実施し, 処理したPVP の分子量および基本構造が末処理のそれ と比較して何ら変化がないことを確認した。

\section{6 這元 PVP の吸光度测定}

得られた還元 PVP の吸光度を測定した。 その結果を Fig. 7 に示した. 還元によるPVP はいずれの方法におい ても, 未処理のあのと比較して, 共役エノンに由来する あのと推定される吸収成分の吸光度に著しい減少がみら れ, 共役エノン構造が還元により対応する孤立ヶトンお るいはヒドロキシルまで還元されたことがわかる.

\section{7 這元 PVP フィルムの光劣化挙動}

得られた還元 PVP のうち, 吸光度の減少がより顕著 であった Na/HMPA 法による改質 PVPについて，未処 理 PVP の場合と同様にフィルムを成型し，これに波長 $365 \mathrm{~nm}$ の紫外光を連続照射してその光劣化挙動につい て検討した. Fig. 8 に $280 \mathrm{~nm}$ での透過率の推移, Fig. 9 にフィルム膜厚の推移を示した。、いずれの結果からも， 末処理のPVP からなるフィルムと比較して劣化の速度 が大幅に緩和されていることが示され，還元による共役 


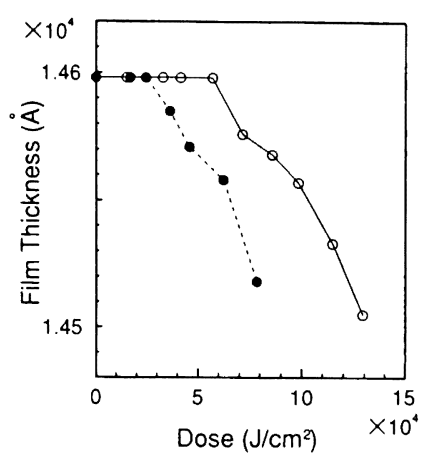

Fig. 9. Decrease of the film thickness of reduced poly(vinyl propional) at $280 \mathrm{~nm}$ upon irradiation with 365 nm UV light: $\bigcirc$, reduced PVP; $\bigcirc$, oridinal PVP.

エノン構造の除去が, ポリマーの光劣化性の改善に効果 的であるこを示す結果を得た.

このことから, PVP の光劣化反応は当初推定したとお り, 主鎖カルボニルと共役エノン構造によって始動され るものであり, あらかじめポリマー中に含まれるこれら の構造を化学的に除去処理することで, 樹脂の光劣化反 応を抑えることができることが明らかとなった。

\section{4 結言}

PVAとプロピオンアルデヒドとのアセタール化体で あるPVP からなるフルムに波長 $365 \mathrm{~nm}$ の紫外光を 連続照射し，フィルムの光劣化について検討した，その 結果, PVP フィルムにおいても PVA と同様の光劣化反 応，すなわちポリマー主鎖へのカルボニルおよび共役エ ノンの生成と, それに続く主鎖開裂が生じている可能性
を見いだした．次にこの結果に基づいて，光劣化に対し てより優れた耐久性を持っ PVP の合成を目指し，ポリ マー中に含まれるこれら主鎖カルボニルと共役エノンの 化学的な除去を目的とする PVP の還元処理を行った. 得られた還元 PVP から成型したフィルムは，未処理 PVPからなるフィルムと比較し, 大幅に光劣化性が改善 することを見いだした。

\section{文献}

1) W. H. Herrmann and W. Heahnel, Ger. Patent 480866 (1924).

2) J. A. Snelgrove, J. Adhesive Assoc., 21, 489 (1985).

3) 藤井雅弘, “ブチラール樹脂”, 高分子刊行会, 京都 (1954), p. 2.

4) I. Ward, U. S. Patent 4476172 (1984).

5) I. Ward and Duly, SPIE Proceedings on Optical Microlithography. III, Vol. 470, (1984), pp. 147 156.

6) 内倉昌樹 (東ソ一), 特開昭 63-163462 (1988).

7) W. N. Partlo and W.G. Oldham, SPIE Proceedings on Optical Microlithoglaphy. III, Society of Photo-Optical Instrumentation, Engineers (SPIE), 1264 (1990), pp. 564 575.

8) T. A. Brunner, C. P. Ausschnitt, and D. L. Duly, Solid State Technology, May, 135 (1983).

9) 青木弘行, 大橋秀行, 鈴木 邁, 材料, 24, 129 (1975).

10）青木弘行, 上原 勝, 鈴木 薄, 材料, 27, 1141 (1978).

11) Etsuo Niki, Yoshihiro Yamamoto, and Yoshio Kamiya, Adv. Chem. Ser., 169, 78 (1978).

12) 山口 格, 天笠正孝, 絹巻 丞, 高橋忠男, 高分子化学, 16, 571 (1959).

13）網屋繁俊, 高分子, 36, 10 (1987).

Photodegradation of Poly(vinyl propional) Film, and Improvement of Photodegradative-Durability by Chemical Reduction of the Polymer

Takashi YAMAMOTO*1 and Toru SEITA*1

*1 Advanced Materials Research Laboratory, Tosoh Corp. (2743-1 Hayakawa, Ayase, 252 Japan)

Photodegradation behavior of poly(vinyl propional) films upon irradiation with UV light at $365 \mathrm{~nm}$ wavelength was investigated by several spectroscopic analyses. It was inferred that the photodegradation involves the photooxidative reaction similar to that of poly (vinyl alchol). On the basis of this observation, the polymer was subjected to reductive treatment to remove carbonyl structures and enone structures, which were detected in trace amounts in the original polymer. This treatment improved the photodegradative-durability of the film markedly.

KEY WORDS Photodegradation / Poly(vinyl propional) / Reduction / Poly(vinyl alcohol) /

Photooxidative Reaction /

(Received May 24, 1994: Accepsed June 20, 1994)

[Kobunshi Ronbunshu, 51(12), 789-794 (1994)] 